\title{
Optimization of Glucose Production of Cocopeat Using Whole Cell Trichoderma reesei
}

\author{
Muhammad Zaki ${ }^{*}$, Suhendrayatna ${ }^{1}$, Misbul Hadi $^{1}$, and Syukri Adha ${ }^{1}$ \\ ${ }^{1}$ Chemical Engineering Departement, Faculty of Engineering, Syiah Kuala University
}

\begin{abstract}
The high content of cellulose in cocopeat makes this material convertible into glucose. The converting process of cellulose into glucose can be done by hydrolysis. In this research, the coocopeat hydrolyzed enzymatically using cellulose ezyme from Trichoderma reesei. The purpose of this study was to obtain optimum conditions of glucose yield and to know the effect of concentration of $\mathrm{NaOH}$, molasses mass, and the effect of hydrolisis time on glucose yield produced. The variabel used was hydrolisis time ( 0 ; 124; and 240 hour), $\mathrm{NaOH}$ concenteration ( $1 \% ; 2 \%$; and $3 \%$ ), and molasses mass (40; 50; and $60 \mathrm{gr} / 1)$. The result showed the higest glucose level obtained at $2 \% \mathrm{NaOH}$ concenteration, molasses mass 60 gram, and hydrolysis time 240 hours, while the predicted resulted of the optimum conditions of glucose level produced using the software Design Expert 6.08 is $776.771 \mathrm{mg} / \mathrm{l}$ at $\mathrm{NaOH}$ concenteration 1,35\%, molasses mass $59.96 \mathrm{mg} / \mathrm{l}$ and hydrolisis time 215.62 hours.
\end{abstract}

\section{Introduction}

Cocopeat is one type of solid waste from coconut processing industry that commonly found in Indonesia. In 2014, Indonesia has a coconut plantation area about 3.65 million hectares with total production of 3.05 million tons per year [1]. The availability of coconut plantations that make a lot of cocopeat waste abundant in Indonesia, until now the utilization of cocopeat waste is still very limited due to the lack of existing technology. One coconut can produce about 400 grams of coconut husk with $75 \%$ fiber and $25 \%$ cork composition, so the cocopeat content in one coconut is about 100 grams $[2,3]$.

One of the benefits of waste cocopeat is can be used as raw material for glucose production with involves Trichoderma reesei fungus, because its contents of $43.44 \%$ cellulose [4]. The converting process of cellulose into sugars can be done by hydrolysis, which can be done either chemically or enzymatically. Chemical hydrolysis process can be carried out by using acid solution with pressure more than 1 atm and temperature above $200^{\circ} \mathrm{C}$ [4]. Meanwhile, cellulose hydrolysis process using $1 \%$ sulfuric acid $\left(\mathrm{H}_{2} \mathrm{SO}_{4}\right)$ at a temperature of $215^{\circ} \mathrm{C}$ with a conversion of $50 \%$ [5]. This acidic hydrolysis process is difficult because it's determining difficulty in operating conditions that make this process less effective and requires a lot of energy, also makes the tools to be corrosive, less environmentally friendly, and can produce such furfural disruptive compounds.

Compared to the chemical hydrolysis, enzymatic hydrolysis is more advantageous. The enzymatic hydrolysis process does not degrade the sugar during hydrolysis process, occur at low temperatures, and lower equipment maintenance costs because there is no corrosive as well as environmentally friendly [6]. Enzymatic hydrolysis of cellulose generally uses microbes that can produce cellulose enzymes, Trichoderma $s p$ is one of the fungi species that can produce the enzyme [4].

Research that discusses the conversion of cellulose into glucose by using Trichoderma reesei fungi has been widely reported. Hydrolysis of coconut husk using Trichoderma reesei with coconut fiber concentration of $5 \mathrm{~g} / \mathrm{ml}$ and the same inoculum concentration can yield $0.8 \mathrm{gr} / \mathrm{ml}$ of glucose [4]. In another study using cocopeat as a feedstock yielded the highest glucose concentration at a time of 7 days hydrolysis with glucose levels of $193.25 \mathrm{mg} / 1$ [7]. Base on the earlier results research, this research was focused to find the optimum condition of hydrolysis cocopeat process to glucose by using Trichoderma reseei fungi.

\section{Materials and Methods}

\subsection{Materials}

All chemicals used in the form of grade reagent were obtained commercially from Waco ltd. Trichoderma reese $i$ were obtained from the stock culture of School of Life Sciences and Technology, Bandung Institute of Technology. Cocopeat was obtained from coconut farmers around Darussalam, Banda Aceh City. Before use, cocopeat was dried under the sun for 3 days and then cocopeat subsequently shredded and sieved.

Corresponding author: m.zaki@che.unsyiah.ac.id 


\subsection{Experimental Procedure}

Ten grams of cocopeat was mixed with various $\mathrm{NaOH}$ solution $(1,2$, and $3 \%)$ at a ratio of $1: 10(\mathrm{gr} / \mathrm{ml})$, the sample was then stirred and heated for 2 hours to remove the lignin. Treatment was followed by washing until the $\mathrm{pH}$ of wash water become neutral and then drying in the oven. The setting of equipment is shown in Figure 1.

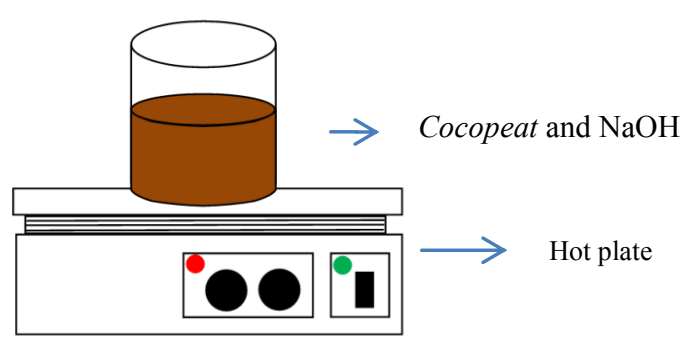

Fig. 1. Setting of equipment

\subsection{Glucose Analysis}

Glucose content analysis was performed by Di-Nitro salicylates (DNS) method. Two ml DNS reagent mixed with $2 \mathrm{ml}$ of liquid sample and then the mixture was heated to $80-100^{\circ} \mathrm{C}$ for 5 minutes to develop a red-brown color. The mixture then was added $1 \mathrm{ml}$ of $40 \%$ sodium potassium tartrate solution (rochelle salt). After the color of mixture stabilized, the solution was cooled and the absorbance was measured by using UV-VIS spectrophotometer, Shimadzu 1700.

\subsection{Data Analysis}

Experimental design was carried out using Box-Behnken design with supported by Design Expert 6.0.8 software.
The data was processed using ANOVA. Table 1 performs an experimental design using Design Expert 6.0.8 software.

Table 1. Experimental design.

\begin{tabular}{|c|c|c|c|}
\hline Run & $\begin{array}{c}\text { NaOH Conc. } \\
(\mathbf{\%})\end{array}$ & $\begin{array}{c}\text { Molasses } \\
\text { mass (gr) }\end{array}$ & $\begin{array}{c}\text { Hydrolysis } \\
\text { Time (Hours) }\end{array}$ \\
\hline 1 & 3 & 40 & 120 \\
\hline 2 & 1 & 50 & 240 \\
\hline 3 & 3 & 50 & 0 \\
\hline 4 & 2 & 50 & 120 \\
\hline 5 & 2 & 50 & 120 \\
\hline 6 & 2 & 50 & 120 \\
\hline 7 & 1 & 60 & 120 \\
\hline 8 & 2 & 60 & 0 \\
\hline 9 & 1 & 40 & 120 \\
\hline 10 & 2 & 40 & 240 \\
\hline 11 & 2 & 50 & 120 \\
\hline 12 & 2 & 40 & 0 \\
\hline 13 & 3 & 60 & 120 \\
\hline 14 & 2 & 60 & 240 \\
\hline 15 & 1 & 50 & 0 \\
\hline 16 & 2 & 50 & 120 \\
\hline 17 & 3 & 50 & 240 \\
\hline
\end{tabular}

\section{Results and Discussion}

\subsection{Summary of surface response statistics model}

The statistical model summary provides suggestions for the selection of appropriate models and compatibility with experimental data. Table 2 shows statistical model for the glucose content analysis resulting from the BoxBehnken design. The suggested model was quadratic and linear.

Table 2. Summary of statistical model.

\begin{tabular}{|c|c|c|c|c|c|}
\hline Cubic & Std. Dev. & $\begin{array}{c}\text { R- } \\
\text { Squared }\end{array}$ & $\begin{array}{c}\text { Adjusted } \\
\text { R-Squared }\end{array}$ & $\begin{array}{c}\text { Predicted R- } \\
\text { Squared }\end{array}$ & Result \\
\hline Linear & 187.55 & 0.5366 & 0.4297 & 0.1208 & Suggested \\
\hline 2FI & 196.27 & 0.6097 & 0.3754 & -0.6285 & \\
\hline Quadratic & 102.59 & 0.9253 & 0,8294 & $-0,1944$ & Suggested \\
\hline Cubic & 0 & 1 & 1 & & \\
\hline
\end{tabular}

Since the quadratic has a value $\mathrm{R}^{2}$ closer to one (0.9253) and Adj- $\mathrm{R}^{2}$ is 0.8294 , the suggested model is chosen quadratically. If the value of $\mathrm{R}^{2}$ close to 1 identifies that there is a high correlation between the observed value and the predicted value [8]. The best modeling is focused on Adj- $R^{2}$ value and maximum $R^{2}$ value [9]. The value of $R^{2}$ is the value that describes the ratio of a variation ratio to total variation and the level of conformity of the resulting model. The value of Adj $\mathrm{R}^{2}$ generated by this research model was 0.8289 , which means that the concentration of $\mathrm{NaOH}$ and hydrolysis time greatly affect the diversity of resulting response, while the rest was influenced by other factors not used in this study.

The Box-Behnken design used to produce a mathematical model was actually used to predict the value of glucose levels based on the suggested model. Based on the quadratic model, the equations of the mathematical model generated are as follows: 
$\mathrm{Y}=661,49138+451,33987 \mathrm{X}_{1}-44,36996 \mathrm{X}_{2}+$ $5,66925 \mathrm{X}_{3}-80,76300\left(\mathrm{X}_{1}^{2}\right)+0,45039\left(\mathrm{X}_{2}^{2}\right)-0,017623$ $\left(\mathrm{X}_{3}^{2}\right)-1,16445\left(\mathrm{X}_{1} \cdot \mathrm{X}_{2}\right)+0,98519\left(\mathrm{X}_{1} \cdot \mathrm{X}_{3}\right)+$ $0,052039\left(X_{2} \cdot X_{3}\right)$

Based on the equation model (1) generated above, each variable was the concentration of $\mathrm{NaOH}\left(X_{1}\right)$, molasses mass $\left(\mathrm{X}_{2}\right)$ and hydrolysis time $\left(\mathrm{X}_{3}\right)$. These three variables have a very important influence where the use of these three variables will increase the resulting glucose levels. From the equation (1) obtained results predicted value of glucose levels produced that was tabulated in Table 3.

Table 3. Comparison research and prediction data (Design expert) for glucose levels.

\begin{tabular}{|c|c|c|c|c|c|}
\hline \multirow[b]{2}{*}{ Run } & \multirow[b]{2}{*}{$\begin{array}{c}\mathrm{NaOH} \\
\text { Concentratio } \\
\text { n }(\%)\end{array}$} & \multirow[b]{2}{*}{$\begin{array}{l}\text { Molases } \\
\text { mass (gr) }\end{array}$} & \multirow[b]{2}{*}{$\begin{array}{l}\text { Hydrolysis } \\
\text { Time } \\
\text { (Hours) }\end{array}$} & \multicolumn{2}{|c|}{ Glucose (mg/l) } \\
\hline & & & & Research & $\begin{array}{c}\text { Prediction } \\
\text { (Desain } \\
\text { expert) }\end{array}$ \\
\hline 1 & 3 & 40 & 120 & 506.05 & 416.39 \\
\hline 2 & 1 & 50 & 240 & 625.26 & 614.88 \\
\hline 3 & 3 & 50 & 0 & 0 & 0 \\
\hline 4 & 2 & 50 & 120 & 534.47 & 534.48 \\
\hline 5 & 2 & 50 & 120 & 534.47 & 534.48 \\
\hline 6 & 2 & 50 & 120 & 534.47 & 534.48 \\
\hline 7 & 1 & 60 & 120 & 514.74 & 604.4 \\
\hline 8 & 2 & 60 & 0 & 0 & 0 \\
\hline 9 & 1 & 40 & 120 & 435.79 & 489.42 \\
\hline 10 & 2 & 40 & 240 & 509.21 & 466.01 \\
\hline 11 & 2 & 50 & 120 & 534.47 & 534.48 \\
\hline 12 & 2 & 40 & 0 & 0 & 0 \\
\hline 13 & 3 & 60 & 120 & 538.42 & 484.8 \\
\hline 14 & 2 & 60 & 240 & 761.84 & 682.6 \\
\hline 15 & 1 & 50 & 0 & 0 & 0 \\
\hline 16 & 2 & 50 & 120 & 534.47 & 534.48 \\
\hline 17 & 3 & 50 & 240 & 149.21 & 282.12 \\
\hline
\end{tabular}

Comparison of research data with predictive data shows in Table 2. Center point condition was in Run 5 as much as $50 \mathrm{gr}$ of molasses, $2 \% \mathrm{NaOH}$ concentration, hydrolysis time of 120 hours, and glucose production level of $534.47 \mathrm{mg} / \mathrm{l}$. Table 2 also shows that the highest glucose levels. The plotting data between research results and predicted results of the expert design was shown in Figure 2. This figure shows the relationship of prediction values based on the equations proposed by the response surface design and the actual values generated from the experiments. It can be seen that the points on the chart were spread on a straight line and this condition shows the good accuracy of the model obtained.

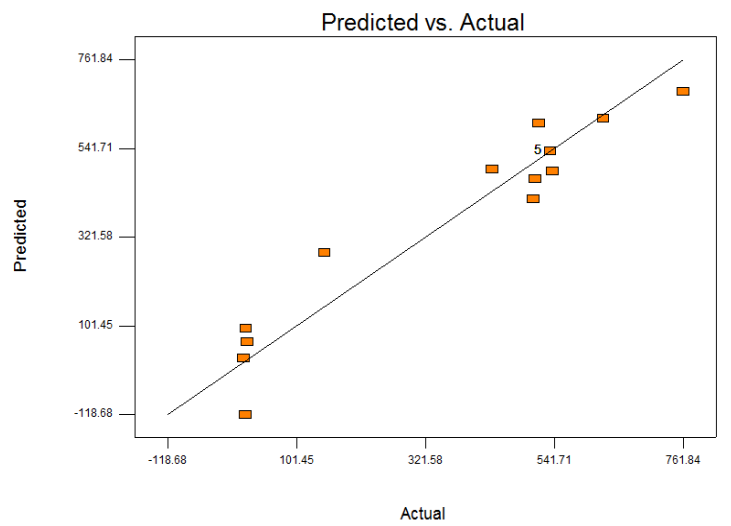

Fig. 2. Relationship between glucose levels of the results of research and prediction.

\subsection{Analysis of Variants (ANOVA)}

ANOVA is one of the factorials of Box-Behnken design that is useful for generating interaction between process variables and response variables. The components in ANOVA will be used to calculate the F-ratio that serves to determine the effectiveness of a model [10]. Figure 4.2 shows that most of the resulting models from this research were significant. It is proved that the resulting prob. $>$ F value was $<0.05$. The model acceptable if the $\mathrm{P}$ value was less than $5 \%(0.05)$ which means the model can represent a significant influence on response [9]. The result of variance analysis showed that both linear factors were significant to the response, whereas for the quadratic, the concentration of $\mathrm{NaOH}$, molasses mass, and hydrolysis time had a significant effect on the resultant response. 
ANOVA for Response Surface Quadratic Model

Analysis of variance table [Partial sum of squares]

\begin{tabular}{|c|c|c|c|c|c|c|}
\hline & Sum of & & Mean & $F$ & & \\
\hline Source & Squares & DF & Square & Value & Prob $>F$ & \\
\hline Model & $9.132 E+005$ & 9 & $1.015 E+005$ & 9.64 & 0.0034 & significant \\
\hline A & 18553.45 & 1 & 18553.45 & 1.76 & 0.2259 & \\
\hline B & 16816.77 & 1 & 16816.77 & 1.60 & 0.2467 & \\
\hline C & $4.942 E+005$ & 1 & $4.942 E+005$ & 46.96 & 0.0002 & \\
\hline$A^{2}$ & 27463.84 & 1 & 27463.84 & 2.61 & 0.1502 & \\
\hline$B^{2}$ & 8541.10 & 1 & 8541.10 & 0.81 & 0.3976 & \\
\hline$c^{2}$ & $2.712 E+005$ & 1 & $2.712 E+005$ & 25.77 & 0.0014 & \\
\hline$A B$ & 542.38 & 1 & 542.38 & 0.052 & 0.8269 & \\
\hline$A C$ & 55906.95 & 1 & 55906.95 & 5.31 & 0.0546 & \\
\hline$B C$ & 15598.64 & 1 & 15598.64 & 1.48 & 0.2629 & \\
\hline Residual & 73667.55 & 7 & 10523.94 & & & \\
\hline Lack of Fit & 73667.55 & 3 & 24555.85 & & & \\
\hline Pure Error & 0.000 & 4 & 0.000 & & & \\
\hline Cor Total & $9.868 E+005$ & 16 & & & & \\
\hline
\end{tabular}

Fig. 3. ANOVA for quadratic model.

\subsection{Analysis of Surface Response to Glucose Levels}

The model suggested to calculate glucose level in this research was quadratic equation. Model selection was based on several factors, such as the value of $\mathrm{R}^{2}$. From the model that based on response surface analysis, it used two types of plots, namely contour plots and and 3D plots. This plot was used to facilitate description of the effect of variables on the response. The contour plot was a $2 \mathrm{D}$ plot which was the transverse slice of the $3 \mathrm{D}$ plot. Contour plots were useful for analyzing the interaction effects among factors on response [11]. The 3D plot shows the effect of two variables on the response to which the variable was made in a fixed state. The model equation suggested by software design expert version 6.0.8 for glucose production was the quadratic model equation. To analyze this model, threedimensional plots and contour plots can be used. The relationship between the three independent variables to the response can be seen in Figure 4 and Figure 5, respectively.

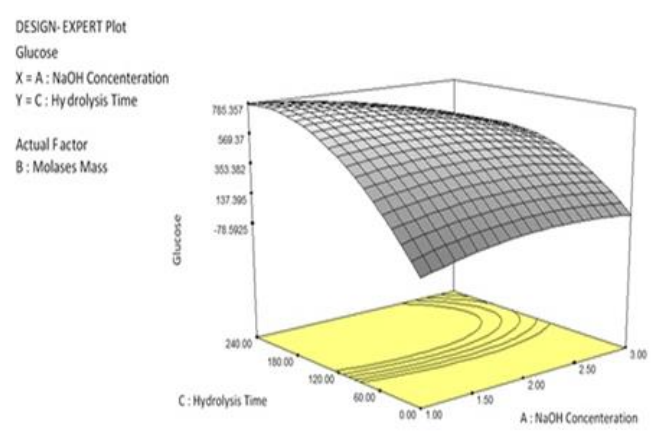

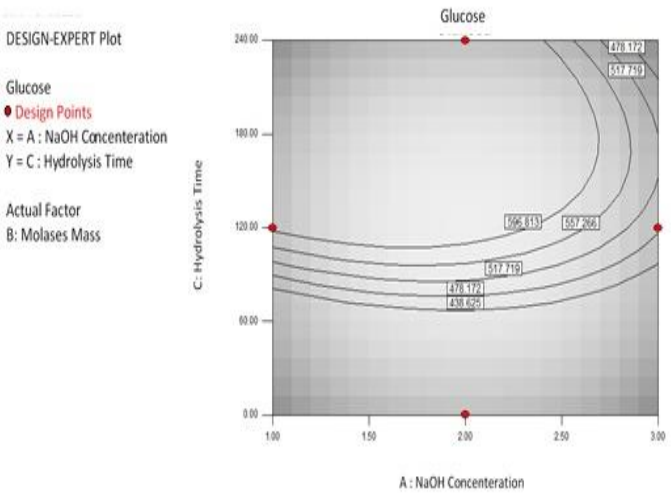

Fig. 4. Effect of $\mathrm{NaOH}$ concentration and hydrolysis time on glucose level production (a) 3D Plot (b) Contour Plot.

Figure 4 shows the effect of $\mathrm{NaOH}$ concentation on the delignification process on glucose level product. Cocopeat used in this study still contains some impurities such as lignin. The presence of lignin in the cocopeat substrate can decrease the rate of cellulosic decomposition, because lignin can adsorb the cellulase enzyme thus reducing the amount of enzymes adsorbed by cellulose and hemicellulose, therefore before hydrolysis process was occurred, a delignification process was first performed to remove lignin in cocopeat [4]. Delignification is a mass removal process of lignin contained in cocopeat. There are 4 types of delignification method, that is biologically, physically, chemically and physically chemically [12]. The method of delignification used in this research was chemically by addition of Sodium Hydroxide $(\mathrm{NaOH})$ with different concentration $(1 \%, 2 \%$, and $3 \%)$. NaOH was used as a delignifier because $\mathrm{NaOH}$ can damage lignin structure. In addition to damage the lignin structure, $\mathrm{NaOH}$ can also dissolve lignocellulose, but not able to dissolve cellulose, only some of the cellulose can be dissolved in $\mathrm{NaOH}$ due to the degree of polymerization [12]. The difference of $\mathrm{NaOH}$ concentration used in this study aims to know the effect of delignification on glucose levels formed.

Based on the results of research and data processing using Design Expert showed that $\mathrm{NaOH}$ concentrate greatly affect the resultant glucose concentration, at $1 \%$ $\mathrm{NaOH}$ concentration (with molasses 40 grams and hydrolysis time 120 hours) yield glucose level became $435.79 \mathrm{mg} / \mathrm{l}$, while at $3 \% \mathrm{NaOH}$ concentration (with molasses 40 grams and hydrolysis time of $120 \mathrm{~h}$ ) obtained $506.05 \mathrm{mg} / \mathrm{l}$. However, the highest glucose levels reached $761.84 \mathrm{mg} / \mathrm{l}$ that were obtained at $2 \%$ $\mathrm{NaOH}$ concentration (with molasses $60 \mathrm{~g}$ and hydrolysis time of $240 \mathrm{~h}$ ). 

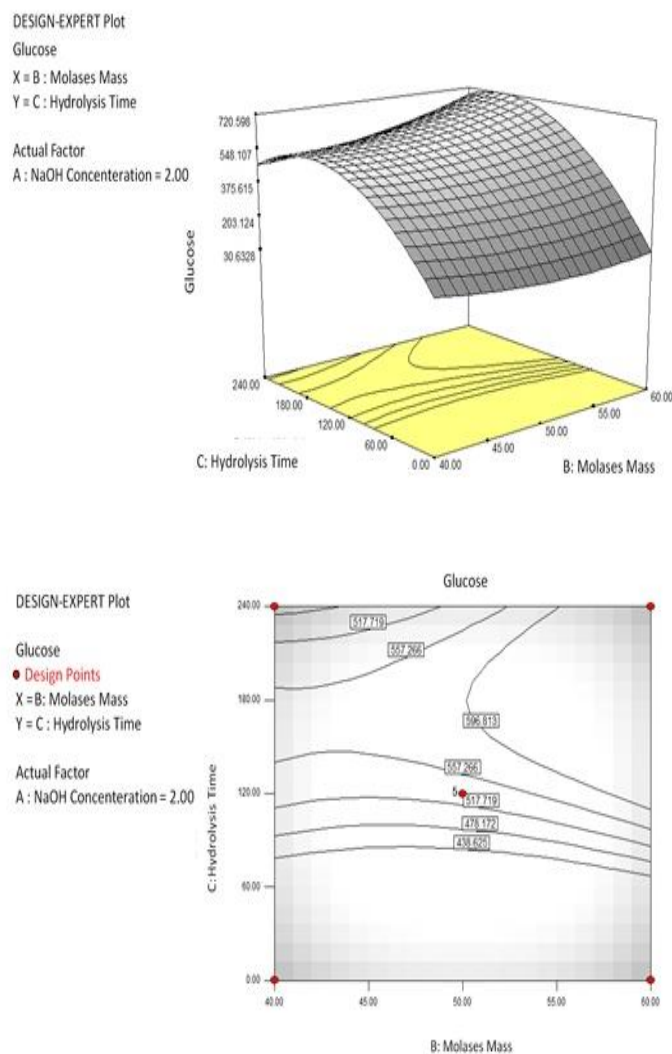

Fig. 5. Effect of molasses concentration and hydrolysis time on the glucose level production (a) 3D Plot (b) Contour Plot

Figure 5 shows the effect of molasses concentration added to the Trichoderma reesei culture on the glucose level production. Molasses are a source of nutrients used for the growth of the mycelium of the Trichoderma reesei mycelium in which the mycelium may secrete the cellulose enzyme used for hydrolysis process. Better nutrients added to the fungus, more enzymes will be produced by the fungus therefore more enzymes produced, hydrolyzed cellulose will increase into glucose and glucose production will be higher.

Figure 4 and Figure 5 also show the profile of glucose levels produced during the hydrolysis process from 0 to 240 hours. Results of the measurement of glucose levels showed that the treatment that received highest glucose level of $761.84 \mathrm{mg} / \mathrm{l}$ occurred at 240 hours. The increase in glucose levels produced shows interaction between cellulose enzyme and cellulose substrate present in cocopeat which will form a complex bond between enzyme and glucose-producing substrate. The interaction between the cellulose enzyme and the substrate at the time of hydrolysis with longer time span causes the reaction to run maximum so the glucose level production becomes higher.
Table 4. Optimum conditions of glucose levels.

\begin{tabular}{|c|c|}
\hline Variabel & Value \\
\hline Molases & 59.95 \\
\hline NaOH (\%) & 1.35 \\
\hline Time (hours) & 215.62 \\
\hline Glucose (mg/L) & 776.771 \\
\hline Desirability & 1 \\
\hline
\end{tabular}

\subsection{Optimization Glucose levels}

The optimization process was carried out by regulating $\mathrm{NaOH}$ concentration, molasses concentration, and hydrolysis time adjusted according to the level range. The response variable as glucose concentration was pointed maximum to obtain the highest yield. Table 4 and Figure 6 show the optimum results of glucose production from cocopeat using Trichoderma reesei. The optimum conditions of process will be achieved at molasses mass of $59.95 \mathrm{gr}, 1.35 \% \mathrm{NaOH}$ concentration, and hydrolysis time of 215.62 hours. Figure 6 shows a $3 \mathrm{D}$ plot image and contour plot of the optimum conditions suggested to produce the highest glucose levels.

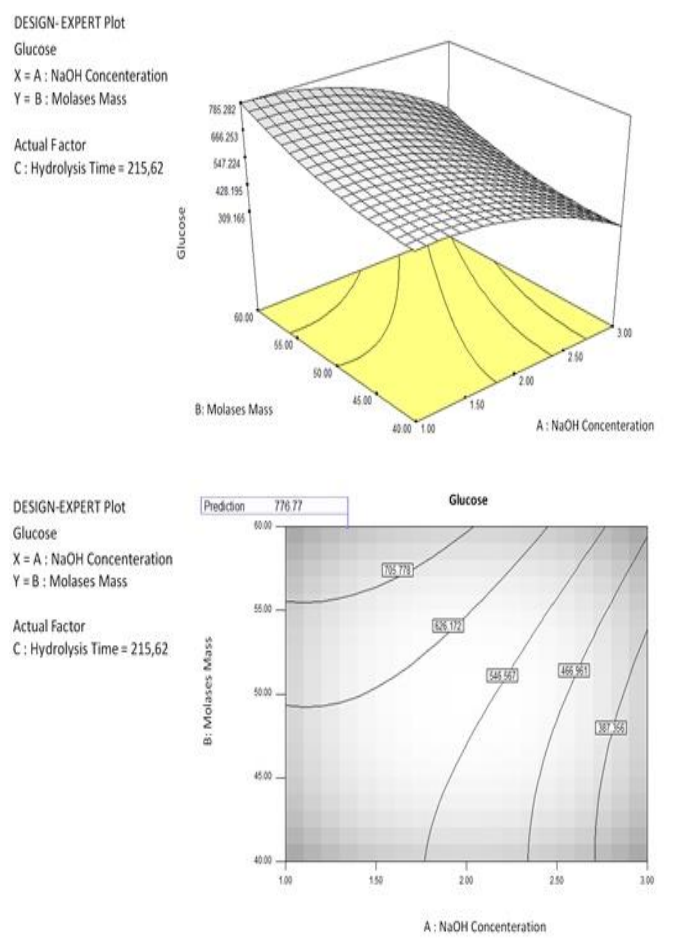

Fig. 6. Model of optimum conditions of glucose levels production (a) 3D Plot (b) Contour Plot for optimum glucose concentration.

\section{Conclusion}

Based on the results described above, it can be concluded that cocopeat can be hydrolyzed by using 
Trichoderma reesei fungus. The higest glucose level obtained at $2 \% \mathrm{NaOH}$ concenteration, molasses mass 60 gram, and hydrolysis time 240 hours, while the predicted resulted of the optimum conditions of glucose level produced using the software Design Expert 6.08 is $776.771 \mathrm{mg} / \mathrm{l}$ at $\mathrm{NaOH}$ concenteration $1.35 \%$, molasses mass $59,96 \mathrm{mg} / \mathrm{l}$ and hydrolisis time 215.62 hours.

\section{References}

1. Directorate General of Plantation, Statistics of Indonesian Plantation. Jakarta (2014)

2. I. Isroful, http:// isroful. Wordpress.com/2009/ 10/ 15/ pengolahan-sabut-kelapa-menjadi-papanpartikel-dengan-batang-pisang-sebagai-pelapisnyapada-interior-bangunan/ (2009)

3. Y. Awang, A. S. Shaharom, R.B. Mohamad and A. Selamat, American Journal of Agricultural and Biological Sciences 4, 1 (2009)

4. S. Sukadarti, S.D Kholisoh, H. Prasetyo, W.P. Santoso, T. Mursini, Journal of Chemical Technology Development for Indonesia Natural Resources, D13-1 (2010)

5. Q. Xiang, Applied Biochemistry and Biotechnology, 107, 1-3 (2003)

6. S. Safaria, N. Idiawati, T.A. Zaharah, J. KK, 2, 1 (2013).

7. M. Refi, D. Rahmadi, Thesis, Syiah Kuala University, (2016)

8. Q. Zhao, J.F. Kennedy, X. Wang, International Journal of Biological Macromolecules, 49, 2011.

9. Ulilalbab, T. Estiasih, Varietas, (2012)

10. C. Hanraha, E. Garza, E. Garcia, K. Miller, 2007. Journal of Environmental Informatics 9, 2 (2007)

11. S.H. Hasan, P. Srivastava, M. Talat, Journal of Hazardous Materials, 168 (2009)

12. A.A. Fajar, Thesis, Bogor Institute of Agricultural (2014) 